\title{
The effect of commercial herbal toothpastes on dental wear: a comparative evaluation by Optical coherence tomography
}

\author{
Efeito dos cremes dentais herbais comerciais no desgaste dentário: uma avaliação comparativa por \\ tomografia de coerência óptica
}

Efecto de las pastas dentales comerciales a base de hierbas sobre el desgaste de los dientes: una evaluación comparativa mediante tomografía de coherencia óptica

Received: 08/19/2021 | Reviewed: 08/23/2021 | Accept: 08/24/2021 | Published: 08/26/2021

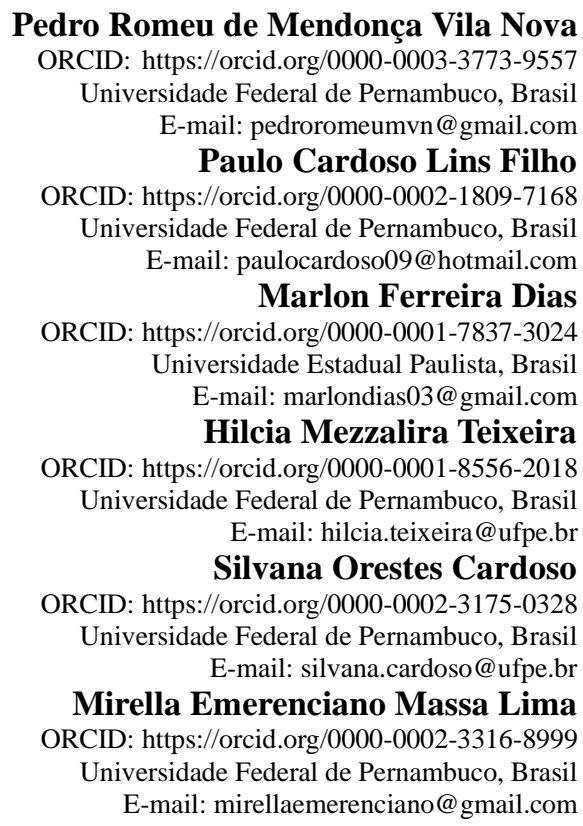

\begin{abstract}
The purpose of this study was to compare the tooth wear in function of the use of different commercial herbal toothpastes through the analysis of Optical Coherence Tomography (OCT). Twenty bovine teeth were obtained and distributed in 4 groups $(n=5)$ according to the dentifrice used: G1: Captive Nature (Chamomile, Xylitol, Juá and Salvia); G2: Suavetex Content (Turmeric); G3: Colgate Triple Action (positive control); G4: distilled water (negative control). The samples were painted in the half of the fragment with nail polish so that only half of the fragment was brushed. The simulated brushing (20,000 cycles) was performed with linear movements, under static axial load of $200 \mathrm{~g}$ and speed of 4.5 cycles per second. After this step, an analysis was performed through OCT and and the images obtained were evaluated to identify possible changes in the specimen surface. According to the qualitative analysis of the OCT images, enamel wear was not observed, since all measurements were null. Regarding the evaluation of dentin, surface wear was observed in all groups except G4, but G3 had the highest number of samples with surface wear around $21.32 \%$. All dentifrices had abrasive wear on the dentin surface to a greater or lesser extent, but there was no wear on the enamel surface.
\end{abstract}

Keywords: Biological products; Dental enamel; Dentin; Toothpastes.

\section{Resumo}

O objetivo deste estudo foi comparar o desgaste dentário em função do uso de diferentes cremes dentais fitoterápicos comerciais por meio da análise de Tomografia de Coerência Óptica (OCT). Foram obtidos 20 dentes bovinos, distribuídos em 4 grupos $(n=5)$ de acordo com o dentifrício utilizado: G1: Natureza Cativa (Camomila, Xilitol, Juá e Salvia); G2: Conteúdo de Suavetex (Cúrcuma); G3: Tripla Ação Colgate (controle positivo); G4: água destilada (controle negativo). As amostras foram pintadas na metade do fragmento com esmalte de unha para que apenas a outra metade do fragmento fosse escovado. A escovação simulada (20.000 ciclos) foi realizada com movimentos lineares, sob carga axial estática de $200 \mathrm{~g}$ e velocidade de 4,5 ciclos por segundo. Após essa etapa, foi realizada uma 
análise através do OCT e as imagens obtidas foram avaliadas para identificação de possíveis alterações na superfície dos espécimes. De acordo com a análise qualitativa das imagens de OCT, não foi observado desgaste do esmalte dental, uma vez que todas as medidas foram nulas. Em relação à avaliação da dentina, o desgaste superficial foi observado em todos os grupos com exceção do G4, porém o G3 apresentou o maior número de amostras com desgaste superficial em torno de $21,32 \%$. Todos os dentifrícios obtiveram um desgaste abrasivo na superfície da dentina em maior ou menor grau, porém não houve desgaste na superfície do esmalte.

Palavras-chave: Produtos biológicos; Esmalte dentário; Dentina; Creme dental.

\section{Resumen}

El objetivo de este estudio fue comparar el desgaste de los dientes en función del uso de diferentes pastas dentales a base de hierbas comerciales mediante el análisis de tomografía de coherencia óptica (OCT). Se obtuvieron veinte dientes de bovino, distribuidos en 4 grupos $(n=5)$ según el dentífrico utilizado: G1: Naturaleza Cautiva (Manzanilla, Xilitol, Juá y Salvia); G2: Contenido de Suavetex (cúrcuma); G3: Colgate Triple Action (control positivo); G4: agua destilada (control negativo). Las muestras se pintaron en la mitad del fragmento con esmalte de uñas de modo que solo se cepilló la otra mitad del fragmento. El cepillado simulado (20.000 ciclos) se realizó con movimientos lineales, bajo una carga axial estática de $200 \mathrm{~g}$ y una velocidad de 4,5 ciclos por segundo. Posterior a este paso, se realizó un análisis mediante el OCT y se evaluaron las imágenes obtenidas para identificar posibles cambios en la superficie de las probetas. Según el análisis cualitativo de las imágenes OCT, no se observó desgaste del esmalte, ya que todas las medidas fueron nulas. En cuanto a la evaluación de la dentina, se observó desgaste superficial en todos los grupos excepto G4, pero G3 tuvo el mayor número de muestras con desgaste superficial alrededor del $21,32 \%$. Todos los dentífricos presentaron desgaste abrasivo en la superficie de la dentina en mayor o menor medida, pero no hubo desgaste en la superficie del esmalte.

Palabras clave: Productos biológicos; Esmalte dental; Dentina; Pastas de dientes.

\section{Introduction}

The expansion of consumption of products developed with natural bases is associated with the values of contemporary society which are related to quality of life in general, beauty, well-being and pleasure, aesthetics, youth and healthy appearance. These values, among other factors, could be obtained from the use of ingredients and formulations from nature (Vecino et al., 2017; Mellou; Varvaresou; Papageorgiou, 2019).

The last decades have registered a growing interest in products considered environmentally sustainable and ecological, this phenomenon has led the personal care and hygiene industry to finance the research and development of products containing natural ingredients and extracts. Allied to this, the promise of products free of chemical additives, and free of harmful side effects, combined with the biological potential of natural extracts, led to the growing search for products with natural formulations (Vecino et al., 2017; Mellou; Varvaresou; Papageorgiou, 2019; Yang et al., 2019).

As a result of this trend, the world and especially European countries are growing a consumer market that is increasingly adept at campaigns called "green consumption", that are products made based on natural assets (Fonseca-Santos; Corrêa; Chorilli, 2015; Kalliath et al., 2018).

Dentifrices are associations of substances that, used in daily brushing, remove exogenous deposits adhered to teeth, making them more resistant to microbial attack as they have the function of enhancing toothbrush's mechanical action. Usually, they are commercially presented in several physical forms, such as paste, powder and gel, highlighting the paste as the most popular formulation, followed by gel (Sanz et al., 2013; Shetty et al., 2017; Resende et al., 2019). These products are composed of: abrasive systems, detergents, flavorings, solvents, humectants, binders, sweeteners, preservatives and an active ingredient. The variety of substances is extensive, which is one of the reasons for the great difficulty in identifying the most appropriate toothpaste for each clinical situation (Sanz et al., 2013; Shetty et al., 2017; Resende et al., 2019). Currently, dentifrices are used to reducing caries, gum and periodontal diseases, dental calculus, dentin hypersensitivity and halitosis (Jardim; Alves; Maltz, 2009; Sanz et al., 2013).

The increased demand for new products, and the growing search for natural bioactive products, inspired studies that seek to better understand the potential of these compounds in maintaining oral health. Previous studies show that these 
compounds present antioxidant, antimicrobial and anti-inflammatory potential when applied in mouthwashes or dental gels formulations (Abhishek et al., 2015; Gomes et al., 2016; Hosadurga et al., 2016; Jurowski et al., 2019; Ashrafi et al., 2019; Korkmaz et al., 2019; Braga et al., 2019), however there is little evidence of how these compounds physically interact with the dental surface, elucidating the potential for wear on dental structures (Kalliath et al., 2018).

In view of this, and knowing that the indiscriminate use of toothpaste associated with the mechanical action of the toothbrush has been associated with an increased prevalence of abrasion of the teeth's hard tissues (Wiegand; Schlueter, 2014; Savage et al., 2019), this study aims to comparatively assess the tooth wear due to use of different toothpastes through Optical Coherence Tomography (OCT) analysis.

\section{Methodology}

This research consisted of an in vitro study, approved by the Ethics Committee on the Use of Animals of the Center for Biological Sciences of the Federal University of Pernambuco (CEUA-CCBB / UFPE), process $n^{\circ} 0064 / 2018$.

Twenty young bovine incisors were distributed into four groups $(n=5)$, divided according to the toothpaste used, with the exception of Groups 3 and 4 (positive and negative control respectively) as described in Table 1.

Table 1 - Division of groups according to the materials used and their respective compositions.

\begin{tabular}{|c|c|c|c|}
\hline GROUPS & ABREVIATION & DENTIFRICE & COMPOSITION \\
\hline Group 1 & G1 & $\begin{array}{c}\text { Dental Gel } \\
\text { Captive Nature } \\
\text { (Chamomile, Xylitol, } \\
\text { Juá and Salvia) }\end{array}$ & $\begin{array}{c}\text { Malaleuca Alternifolia Leaf, Matomaria Chamomila Extract, } \\
\text { Zizyphus Joaseiro Extract, Salvia Officinalis Extract, Mentha } \\
\text { Piperita Essential Oil, Illicium Verum Essential Oil, } \\
\text { Azadirachta Indica Extract, Sorbitol, Silica, Disodium Coconut } \\
\text { Glutamate, }\end{array}$ \\
\hline Group 2 & $\mathrm{G} 2$ & $\begin{array}{l}\text { Toothpaste } \\
\text { SuavetexContente } \\
\text { (Turmeric) }\end{array}$ & $\begin{array}{c}\text { Long Turmeric (Tumeric), Callus Extract (Turmeric), Eugenia } \\
\text { Caryophyllus Leaf Extract (Clove), Flower / Leaf / Stem Extract } \\
\text { of Maleleuca Alternifolia (Malaleuca), Stevioside, Xylitol, } \\
\text { Carrageenan, Xanthan Gum, Glycerin, Lauryl Glycoside, } \\
\text { Calcium Carbonate Silica, Aqua, Aroma. }\end{array}$ \\
\hline Group 3 & G3 & $\begin{array}{c}\text { Toothpaste } \\
\text { Colgate Triple Action }\end{array}$ & $\begin{array}{l}\text { Water, Calcium Carbonate, Sorbitol, Sodium Lauryl Sulfate, } \\
\text { Sodium Monofluorophosphate, Aroma, Cellulose Gum; } \\
\text { Pyrophosphatotetrasodium, sodium bicarbonate, benzyl alcohol, } \\
\text { sodium saccharin, Xanton gum, sodium hydroxide, CI 74260, } \\
\text { CI } 74160 .\end{array}$ \\
\hline Group 4 & G4 & Destilled water & Destilled water \\
\hline
\end{tabular}

Source: Authors.

The specimens were stored in a $2 \%$ chlorhexidine solution (Rioquímica, São Paulo, SP, Brasil) for 12 hours for disinfection and afterwards in distilled water, under refrigeration, for a maximum of six months. Prophylaxis of the teeth was performed manually, using scalpel blades No. 12 (Descarpak, São Paulo, SP, Brasil) to remove the remaining periodontal ligament, and polishing with rubber cups, pumice paste (SS White, São Cristóvão, RJ, Brasil) and water. The specimens were analyzed through a visual examination with a stereoscopic magnifying glass (Compartiner Mercantil Ltda., São Paulo, SP, Brasil) in order to observe the integrity of the enamel surface, so that the specimens that showed defects in the enamel were excluded from the sample. After this procedure, the teeth were stored in distilled water and kept under refrigeration until use.

The teeth were sectioned on buccal and lingual surfaces in the distal and occlusal-cervical directions, with double- 
sided diamond disc (KG SORENSEN, Cotia, SP, Brasil) under abundant refrigeration, to obtain the testing fragments measuring $5 \mathrm{~mm} \times 5 \mathrm{~mm}$. Then, these fragments were included in chemically activated acrylic resin JET (Clássico, Monte Limpo Paulista, SP, Brasil), with the aid of a condensation silicone (COLTENE, Rio de Janeiro, RJ, Brasil) matrix with a $17 \mathrm{~mm}$ diameter central hole. A double-sided tape was used on a glass plate, and the dental fragment was positioned and taken to the silicone matrix, which was covered by acrylic resin. In this way, it was possible to obtain a flat surface of the specimen.

After the polymerization of the acrylic resin, the buccal and lingual surfaces were polished in a polishing machine (Buehler, Uzwil, St. Gallen, Suíça), at a speed of 150 revolutions per minute, with sandpaper of decreasing grain (\# 100, 400, 600 and 1200), until enamel exposure in order to obtain a flat surface. Subsequently, this procedure was repeated in order to remove superficial enamel and expose dentin surface.

After being polished, part of the dental surface was sealed with two layers of nail polish (RISQUE, SP, Brasil) and later the surfaces received the application of adhesive tapes, maintaining an exposed test area of $2 \times 2 \mathrm{~mm}$, so that half of the dental surface is covered, intending not to receive action on the brushing machine, facilitating the visualization before and after brushing in the same specimen. Guides were marked on the acrylic resin for later reading of changes in the enamel and dentin surface by the OCT.

Before each brushing cycle, all samples were subjected to the action of artificial saliva with $\mathrm{pH} 5.5$ for five minutes to simulate the "acid challenge" that occurs after a meal. The mechanical brushing test was performed on MSET (Elquip, São Carlos, SP, Brasil) machine, which simulates brushing cycles. Toothbrushes - (DentalK, Taboão da Serra, SP, Brasil) soft adult brush- were attached to the brushing machine and kept parallel to the specimens. A toothpaste solution was used for brushing (with the exception of G4, which was brushed only with distilled water). To simulate clinical conditions, the solutions were obtained by mixing the toothpaste with distilled water in the proportion of $1: 2$, that is, $90 \mathrm{~g}$ of toothpaste to $180 \mathrm{~mL}$ of distilled water, because in the mouth, during brushing, the toothpaste is diluted in the presence of saliva. The simulated brushing was performed with linear movements, under a $200 \mathrm{~g}$ static axial load and a speed of 4.5 cycles per second, with the complete movement of the toothbrush coming and going.

Each group was subjected to 20,000 brushing cycles, simulating the total brushing time of 24 months, each time performed in $1 \mathrm{~h}$ and 20min of brushing, and for comparison purposes only half of the specimen was brushed, the other half being sealed by the enamel and Scotch tape.

After brushing was finished, the samples were carefully removed and immediately washed under running water for 1 minute so that the abrasive particles of each toothpaste could be removed from the surfaces.

For OCT analyses, one sample at a time was positioned and fixed on the tomography system evaluation table (SROCT: OCP930SR, Thorlabs, NJ, USA) which sent the images to the computer using the OCT 800 Complex-Square program, with LabView programming (National Instruments, Austin, TX, USA), generating two-dimensional images, in cross sections of dental structures. Each image was obtained in an interval of $250 \mu \mathrm{m}$, in this way, we obtained a complete mapping of the sample.

For quantitative analysis, the wear morphometry was performed after brushing, using the ImageJ Software (version 1.41 for Windows), measurements were taken from the margin that did not undergo brushing to the other end that underwent brushing. Calibration was done in Pixels (Px). The data obtained were grouped in a database typed in the Excel spreadsheet and then analyzed statistically.

The data were analyzed descriptively through the measures: mean, standard deviation (mean $\pm \mathrm{SD}$ ), median and 25th and 75th percentiles. Kruskal-Wallis test was used to assess significant difference between groups and in the case of significant difference, tests were used comparisons of that test. It emphasizes that the choice of the Kruskal-Walis test was due to the rejection of the hypothesis of normality of the data. The verification of normality was performed using the Shapiro-Wilk test. 


\section{Results}

Enamel surface analysis shows absence of surface wear in all 4 groups (Figure 1 - Sections A, B, C, D).

Figure 1 - Transverse OCT images from enamel surface of 4 groups after brushing cycles.

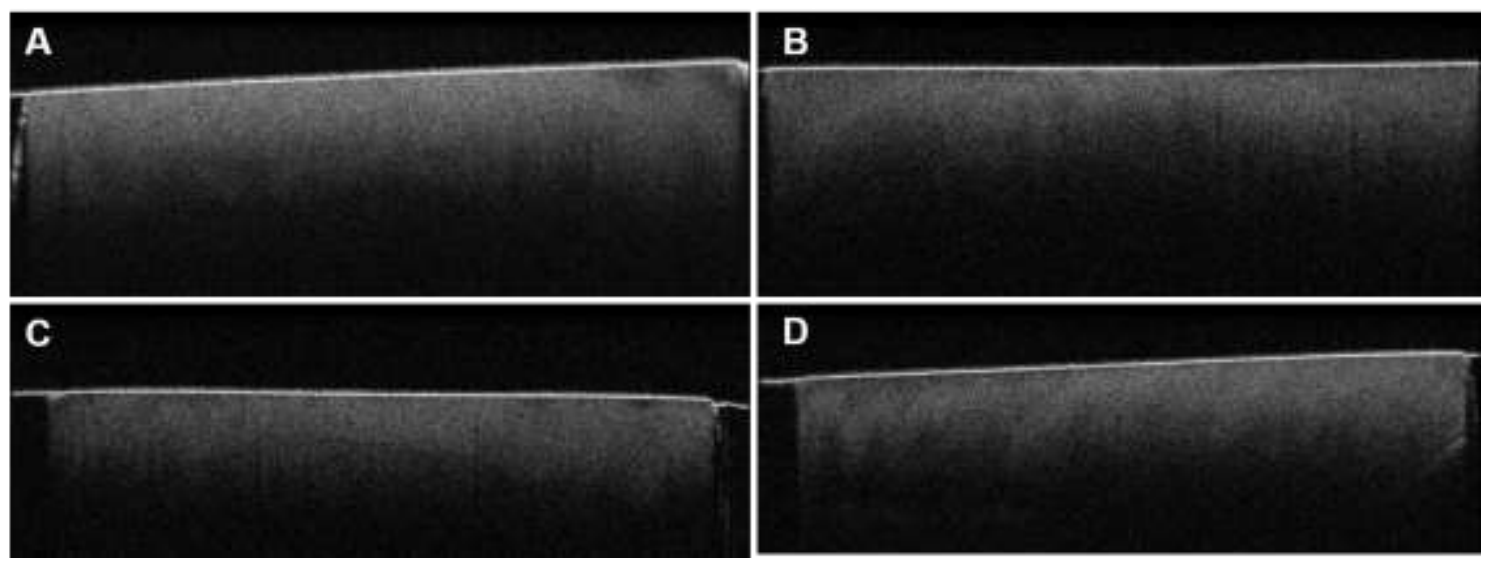

It can be observed the absence of enamel surface wear in each section: A (G1), B (G2), C (G3) and D (G4). Source: Authors.

In dentin, the presence of wear is evident (Figure 2 - Sections A, B, C) and the absence of surface wear (Figure 2 Section D). In the images in which the structural change was evident, it is possible to observe the wear very clearly due to the sealing done before brushing, so that only half of the sample surface was brushed and indicating the occurrence or not of wear.

Figure 2 - Transverse OCT images from different samples.

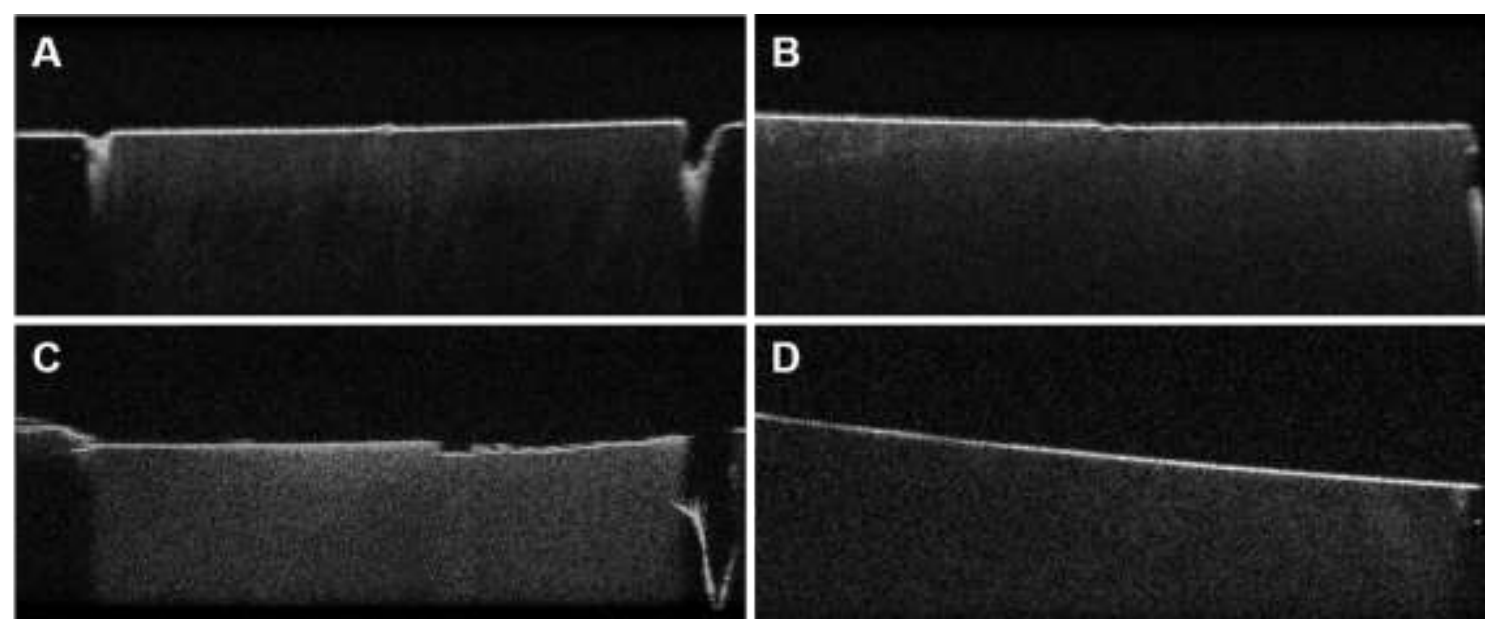

On sections A (G1), B (G2) and C (G3) images it is possible to see a step on the image surface, confirming that there was wear on the dentin surface after the brushing cycle. However, section D (G4) shows that there was no difference in levels between the images before and after brushing. Source: Authors.

Table 2 shows the results of tooth wear on enamel and dentin according to the group. From this table, the enamel analysis showed regular tooth surface, since all tooth wear measures were null. However, in dentin wear evaluation, the mean and median were correspondingly higher in G3 (Colgate Triple Action) with values equal to 21.32 and 11.40 pixels respectively, followed by the values of G2 (Suavetex Contente - Cúrcuma) with values 7.76 and 6.50 pixels. G1 (Captive Nature - Camomile, Xylitol, Juá and Salvia) showed values of 5.40 and 4.20 pixels and these measures were null in G4 (distilled water). 
There was a significant difference between the groups in the dentin evaluation $(\mathrm{p}<0.01)$. The variability in dentin was null in G4 (distilled water) and reduced in G1 and G2, since the values of standard deviations were less than half 1/3 of the corresponding means. However, G3 showed reasonably high on dentin variability, since the standard deviation was higher than the corresponding average.

Table 2 - Wear statistics (pixels) in enamel and dentin according to the group.

\begin{tabular}{|c|c|c|c|c|c|c|}
\hline \multirow[b]{2}{*}{ Surface } & \multirow[b]{2}{*}{ Statistics } & \multicolumn{4}{|c|}{ Group $^{(1)}$} & \multirow[b]{2}{*}{ P value } \\
\hline & & G1 & G2 & G3 & G4 & \\
\hline \multirow[t]{4}{*}{ Enamel } & Average $\pm \mathrm{DP}$ & $0,00 \pm 0,00$ & $0,00 \pm 0,00$ & $0,00 \pm 0,00$ & $0,00 \pm 0,00$ & $\mathrm{p}^{(2)}=1,000$ \\
\hline & Percentile 25 & 0,00 & 0,00 & 0,00 & 0,00 & \\
\hline & Median & 0,00 & 0,00 & 0,00 & 0,00 & \\
\hline & Percentile 75 & 0,00 & 0,00 & 0,00 & 0,00 & \\
\hline \multirow[t]{4}{*}{ Dentin } & Average $\pm \mathrm{DP}$ & $5,40 \pm 1,48^{(\mathbf{A})}$ & $7,76 \pm 1,62^{(\mathbf{B})}$ & $21,32 \pm 14,36^{(\mathbf{C})}$ & $0,00 \pm 0,00^{(\mathbf{D})}$ & $\mathrm{p}^{(2)}=0,001 *$ \\
\hline & Percentile 25 & 4,20 & 6,50 & 11,40 & 0,00 & \\
\hline & Median & 5,20 & 7,40 & 17,20 & 0,00 & \\
\hline & Percentile 75 & 6,70 & 9,20 & 33,30 & 0,00 & \\
\hline
\end{tabular}

(*) Significant difference at the level of 5.0\% (1) G1 $\square$ Captive Nature; G2 $\square$ Suavetex Contente; G3 $\square$ Colgate Triple Action; G4 $\square$ Distilled water (2) Using the Kruskal Wallis test. Obs. If the letters in parentheses are distinct, there is a significant difference between the corresponding groups. Source: Authors.

\section{Discussion}

A large number of therapeutic agents as products to improve cleaning and promote whitening are currently being included in the composition of toothpastes, which may also be interfering with the dental structure loss. The different formulations of dentifrices are determinant for the degrees of structural losses, and thus they should be better studied regarding their abrasive capacity (De Menezes et al., 2015).

Admittedly, the literature highlights abrasives and therapeutic agents as the most important components of toothpaste (Shetty et al., 2017). The most investigated therapeutic agents are fluorides and antimicrobials (chlorhexidine and triclosan), the first with proven effectiveness in dental caries, and the others in reducing plaque and gingivitis rates (Sanz et al., 2013). Natural substances such as chlorophyll, myrrh, pomegranate, sage, eucalyptol, propolis and others, also called herbal, when incorporated in different brands of toothpaste, have proven to be effective in controlling supragingival biofilm, gingivitis and bleeding on probing, comparatively with conventional dentifrices, as well as showing inhibitory effectiveness in strains of S. mutans (Hosadurga et al., 2018; Kharaeva et al., 2020; Alshehri et al., 2019). However, there are few information about the mechanical interaction between herbal based toothpastes and dental surface.

Optical Coherence Tomography (OCT) is a diagnostic method capable of generating images in real time and providing qualitative and quantitative data. In the present study, this method was used to analyze enamel and dentin surfaces. Previous studies also used the OCT as an instrument for reading dental structures, such as enamel and dentin, and showed the effectiveness in visualizing dental surface alterations (Algarni et al., 2016; Machoy et al., 2017; Alghilan et al., 2019; Machoy 
et al., 2019).

Tooth Abrasion occurs due to the friction that generates mechanical wear and is directly linked to brushing, especially among good practitioners of dental hygiene. The common association between the presence of cervical lesions, root exposure and good dental hygiene has reinforced the idea that tooth brushing factors are involved in its development. Disorders in quantity, strength and form of brushing can produce gingival lesions and loss of dental hard tissues (Wiegand; Schlueter., 2014).

Dentifrices intensify the mechanical cleaning action of toothbrushing. However, this cleaning potential can vary widely between different toothpaste formulations depending on type, distribution, size and morphology of the abrasive particles used on each formulation (De Menezes et al., 2004).

Abrasives are generally inorganic salts, practically insoluble in water, these particles have the function of removing residues, preventing the formation of stains or pigmented film and polishing the dental surface (Mathias-Santamaria; Roulet, 2019). Among them, the most common are precipitated calcium carbonate, bi-calcium phosphate, tricalcium phosphate, aluminum oxide, calcium pyrophosphate and silicas (Ganss et al., 2019). Despite the association between toothpaste cleaning potential and the presence of abrasive salts, the quantity present in each formulation and the type of abrasive are linked to noncarious dental lesions (Wiegand; Schlueter, 2014; De Menezes et al., 2004).

In the present study, a significant difference was observed when comparing the results obtained for enamel and dentin. When analyzing the wear on dentin surface, all specimens brushed with toothpaste had superficial loss, except the positive control group (Colgate Triple Action) which achieved a greater increase in structural loss. However, when analyzing the wear on enamel, no specimen showed surface alteration. This fact can be corroborated by previous studies (Hooper et al., 2003; West et al., 2012), which identified that in addition to dentin being more susceptible to wear, the loss of structure was correlated with the abrasiveness of the toothpaste tested.

In the groups where the wear values were higher ( $\mathrm{G} 3$ and $\mathrm{G} 2$ ), calcium carbonate $(\mathrm{CaCO} 3)$ was the abrasive found simultaneously in the two toothpastes. Calcium carbonate in powder form, odorless, insoluble in water and soluble in acids, has been considered as one of the most powerful abrasives (Lopes, Scaramucci, Aranha, 2018; Wang et al., 2016). When comparing the Knoop hardness values $(\mathrm{Kg} / \mathrm{mm} 2)$ of hard dental structures and calcium carbonate, it can be noticed that calcium carbonate $(135 \mathrm{Kg} / \mathrm{mm} 2)$ has a lower degree of hardness than enamel $(320 \mathrm{Kg} / \mathrm{mm} 2)$, but higher than cementum $(40 \mathrm{Kg} / \mathrm{mm} 2)$ and dentin $(50-60 \mathrm{Kg} / \mathrm{mm} 2)$ (34). This fact can justify the results of the research where there was no wear on enamel.

While brushing, there is a greater loss of dentinal structure than enamel, and this abrasion increases proportionally to the brushing time. Thus, the abrasiveness of a toothpaste may increase the wear of eroded dentin, which should be considered by the dentist when prescribing a toothpaste to patients with root exposure (Vertuan et al., 2020).

It is essential that dentists know in detail the toothpastes composition and also when and how to indicate each type present on market in addition to instructing the patient about good oral hygiene techniques in order to reduce the abrasive potential of their brushing (Muntean et al., 2019).

In the literature, several studies (Sanz et al., 2013; Gomes et al., 2016; Hosadurga et al., 2018; Abhishek et al., 2015; Korkmaz et al., 2019) address the use of herbal compounds in dentistry and their positive effects in the therapy of various oral pathologies, acting as a support tool in the prevention and treatment of caries dental disease, periodontal disease and oral candidiasis. However, there is a reduced availability of works that assess the wear and tear of the dental structure by the specific use of herbal dentifrices. In addition to the limitations of an in vitro study, the lack of similar records was also characterized as a limitation for the development of this research, however, the need for further studies that correlated natural inputs and their abrasive capacity was suggested. 


\section{Conclusions}

After analyzing the results, it can be concluded that:

- No evaluated toothpaste promoted abrasive wear on the enamel surface;

- All dentifrices promoted abrasive wear on the dentin surface, to a greater or lesser degree;

- Colgate Triple-Action toothpaste showed a higher degree of wear on dentin surface;

- The toothpaste Cativa Natureza (Chamomile, Xylitol, Juá and Salvia) showed the least degree of wear, followed by the toothpaste Suavetex Contente (Turmeric).

\section{References}

Abhishek, K. N., Supreetha, S., Sam, G., Khan, S. N., Chaithanya, K. H., \& Abdul, N. (2015). Effect of Neem containing Toothpaste on Plaque and Gingivitis-A Randomized Double Blind Clinical Trial. J Contemp Dent Pract, 16(11):880-3.

Alshehri, D., Alqerban, A., \& Samran, A. (2019). Treatment efficacy of photoactivated disinfection versus Salvadora persica gel in experimental gingivitis. Photodiagnosis Photodyn Ther, 101641.

Alghilan, M. A., Lippert, F., Platt, J. A., Eckert, G. J., Gonzalez-Cabezas, C., Fried, D., et al. (2019). In vitro longitudinal evaluation of enamel wear by crosspolarization optical coherence tomography. Dent Mater, 35(10):1464-70.

Algarni, A., Kang, H., Fried, D., Eckert, G. J., \& Hara, A. T. (2016). Enamel Thickness Determination by Optical Coherence Tomography: In vitro Validation. Caries Res, 50(4):400-6.

Ashrafi, B., Rashidipour, M., Marzban, A., Soroush, S., Azadpour, M., Delfani, S., et al. (2019). Mentha piperita essential oils loaded in a chitosan nanogel with inhibitory effect on biofilm formation against S. mutans on the dental surface. Carbohydr Polym, 212:142-9.

Braga, A. S., Girotti, L. D., de Melo Simas, L. L., Pires, J. G, Pela, V. T., Buzalaf, M. A. R., et al. (2019). Effect of commercial herbal toothpastes and mouth rinses on the prevention of enamel demineralization using a microcosm biofilm model. Biofouling, 35(7):796-804

De Menezes, M., Turssi, C. P., Hara, A. T., Messias, D. C., \& Serra, M. C. (2004). Abrasion of eroded root dentine brushed with different toothpastes. Clin Oral Investig, 8(3):151-5.

Fonseca-Santos, B., Corrêa, M. A., \& Chorilli, M. (2015). Sustainability, natural and organic cosmetics: consumer, products, efficacy, toxicological and regulatory considerations. Brazilian Journal of Pharmaceutical Sciences, 51:17-26.

Ganss, C., von Hinckeldey, J., Tolle, A., Schulze, K., Klimek, J., \& Schlueter, N. (2012). Efficacy of the stannous ion and a biopolymer in toothpastes on enamel erosion/abrasion. J Dent, 40(12):1036-43.

Gomes, C. E., Cavalcante, D. G., Filho, J. E., da Costa, F. N., \& da Silva Pereira, S. L. (2016). Clinical effect of a mouthwash containing Anacardium occidentale Linn. on plaque and gingivitis control: A randomized controlled trial. Indian J Dent Res, 27(4):364-9.

Hooper, S., West, N. X., Pickles, M. J., Joiner, A., Newcombe, R. G., \& Addy, M. (2003). Investigation of erosion and abrasion on enamel and dentine: a model in situ using toothpastes of different abrasivity. J Clin Periodontol, 30(9):802-8.

Hosadurga, R., Boloor, V. A., Rao, S. N., \& MeghRani, N. (2018). Effectiveness of two different herbal toothpaste formulations in the reduction of plaque and gingival inflammation in patients with established gingivitis - A randomized controlled trial. J Tradit Complement Med, 8(1):113-9.

Jardim, J. J., Alves, L. S., \& Maltz, M. (2009). The history and global market of oral home-care products. Braz Oral Res, 23 Suppl 1:17-22.

Jurowski, K., Krosniak, M., Folta, M., Tatar, B., Cole, M., \& Piekoszewski, W. (2019). The toxicological analysis of Cu, Mn and Zn as elemental impurities in pharmaceutical herbal products for teething available in pharmacies in Poland. J Trace Elem Med Biol, 53:109-12

Kalliath. C., Mukunda, A., Pynadath, M., Venugopal, V., \& Prethweeraj, J. (2018). Comparison between the effect of commercially available chemical teeth whitening paste and teeth whitening paste containing ingredients of herbal origin on human enamel. Ayu, 39(2):113-7.

Kharaeva, Z. F., Mustafaev, M. S., Khazhmetov, A. V., Gazaev, I. H., Blieva, L. Z., Steiner, L., et al. (2020). Anti-Bacterial and Anti-Inflammatory Effects of Toothpaste with Swiss Medicinal Herbs towards Patients Suffering from Gingivitis and Initial Stage of Periodontitis: from Clinical Efficacy to Mechanisms. Dent $J$ (Basel), 8(1).

Korkmaz, F. M., Ozel, M. B., Tuzuner, T., Korkmaz, B., \& Yayli, N. (2019). Antimicrobial activity and volatile constituent analysis of three commercial herbal toothpastes containing Aloe vera L. and Fragaria vesca L. extracts. Niger J Clin Pract, 22(5):718-26.

Lopes, R. M., Scaramucci, T., \& Aranha, A. C. C. (2018). Effect of desensitizing toothpastes on dentin erosive wear and tubule occlusion. An in situ study. Am J Dent, 31(4):177-83.

Machoy, M., Seeliger, J., Szyszka-Sommerfeld, L., Koprowski, R., Gedrange, T., \& Wozniak, K. (2017). The Use of Optical Coherence Tomography in Dental Diagnostics: A State-of-the-Art Review. J Healthc Eng, 2017:7560645. 
Research, Society and Development, v. 10, n. 11, e161101119583, 2021

(CC BY 4.0) | ISSN 2525-3409 | DOI: http://dx.doi.org/10.33448/rsd-v10i11.19583

Machoy, M. E., Koprowski, R., Szyszka-Sommerfeld, L., Safranow, K., Gedrange, T., \& Wozniak, K. (2019). Optical coherence tomography as a noninvasive method of enamel thickness diagnosis after orthodontic treatment by 3 different types of brackets. Adv Clin Exp Med, 28(2):211-8.

Mathias-Santamaria, I. F., \& Roulet, J. F. (2019). The effect of diamond toothpastes on surface gloss of resin composites. Am J Dent, 32(4):169-73.

Mellou, F., Varvaresou, A., \& Papageorgiou, S. (2019). Renewable sources: applications in personal care formulations. Int J Cosmet Sci, 41(6):517-25.

Muntean, A., Sava, S., Delean, A. G., Mihailescu, A. M., Dumitrescu, L. S., Moldovan, M., et al. (2019). Toothpaste Composition Effect on Enamel Chromatic and Morphological Characteristics: In Vitro Analysis. Materials (Basel), 12(16).

Resende, A. H. M., Farias, J. M., Silva, D. D. B., Rufino, R. D., Luna, J. M., Stamford, T. C. M., et al. (2019) Application of biosurfactants and chitosan in toothpaste formulation. Colloids Surf B Biointerfaces, 181:77-84.

Sanz, M., Serrano, J., Iniesta, M., Santa Cruz, I., Herrera, D. (2013). Antiplaque and antigingivitis toothpastes. Monogr Oral Sci, 23:27-44.

Savage, K. O., Oderinu, O. H., Oginni, A. O., Uti, O. G., Adegbulugbe, I. C., \& Dosumu, O. O. (2019). Dentine hypersensitivity and associated factors: a Nigerian cross-sectional study. Pan Afr Med J, 33:272.

Singh, R. P., Sharma, S., Logani, A., Shah, N., \& Singh, S. (2016). Comparative evaluation of tooth substance loss and its correlation with the abrasivity and chemical composition of different dentifrices. Indian J Dent Res, 27(6):630-6.

Shetty, R. N., Shetty, S. B., Janardhanan, S., Shetty, S., \& Raj, K. (2017). Comparative evaluation of effect of use of toothbrush with paste and munident on levels of Streptococcus mutans and gingival health in children: An in vivo study. J Indian Soc Pedod Prev Dent, 35(2):162-6.

Vecino, X., Cruz, J. M., Moldes, A. B., \& Rodrigues, L. R. (2017). Biosurfactants in cosmetic formulations: trends and challenges. Crit Rev Biotechnol, 37(7):911-23.

Vertuan, M., de Souza, B. M., Machado, P. F., Mosquim, V., \& Magalhaes, A. C. (2020). The effect of commercial whitening toothpastes on erosive dentin wear in vitro. Arch Oral Biol, 109:104580.

Wiegand, A., \& Schlueter, N. (2014). The role of oral hygiene: does toothbrushing harm? Monogr Oral Sci, 25:215-9.

West, N. X., Hooper, S. M., O'Sullivan, D., Hughes, N., North, M., Macdonald, E. L., et al. (2012). In situ randomised trial investigating abrasive effects of two desensitising toothpastes on dentine with acidic challenge prior to brushing. $J$ Dent, 40(1):77-85.

Wang, Y., Mei, L., Gong, L., Li, J., He, S., Ji, Y., et al. (2016). Remineralization of early enamel caries lesions using different bioactive elements containing toothpastes: An in vitro study. Technol Health Care, 24(5):701-11.

Yang, S., Liu, L., Han, J., \& Tang, Y. (2019). Encapsulating plant ingredients for dermocosmetic application: an updated review of delivery systems and characterization techniques. Int J Cosmet Sci. 